\title{
HIV and Men Who Have Sex with Men in South Africa
}

\author{
James A. McIntyre $\cdot$ Helen Struthers
}

Published online: 22 January 2013

(c) Springer Science+Business Media New York 2013

The first reports of homosexual behavior in South Africa date back to the days of the Dutch East India Company settlement at the Cape of Good Hope, but address the criminal penalties for the conduct. Oosterhoff describes in "Sodomy at Sea and in the Cape of Good Hope during the eighteenth century" [1], a 1753 trial of a Dutch man and two Indian slaves, who had committed mutual masturbation at the chicken house at Robben Island, off the coast of Cape Town. The court records reflect that "not satisfied with their devilish frisky stimulation" they had also sodomized each other. The consequence, following their confession, was that the three were bound together with chains and thrown overboard into Table Bay.

Attitudes towards men who have sex with men (MSM) changed little over the next 250 years. Homosexuality was variously ascribed as a foreign vice, brought in by white settlers, or by migrant workers. Visiting the gold rush town of Johannesburg in 1912, British traveller William Scully noted the occurrence in the predominantly male mining settlement $[2,3]$. In his view, though, it was an "undoubted

J. A. McIntyre $(\bowtie) \cdot H$. Struthers

Anova Health Institute, 12 Sherborne Rd, Parktown,

Johannesburg 2193, South Africa

e-mail: mcintyre@pixie.co.za

J. A. McIntyre

School of Public Health and Family Medicine,

University of Cape Town, Cape Town, South Africa

\section{J. A. McIntyre}

Anova Health Institute, PostNet Suite 242, Private Bag X30500,

Houghton, Johannesburg 2041, South Africa

H. Struthers

Department of Internal Medicine, University of Cape Town,

Cape Town, South Africa fact that the Natives from some of the East Coast recruiting areas, as well as from parts of the Tropics, are addicted to those unnatural vices which, according to Holy Writ, occasioned the destruction of the Cities of the Plain".

The apartheid era brought new controls and legal restrictions, with the ruling National Party viewing homosexuality as a "threat to white civilization" [4] and culminating in the 1960s in a clause in the Immorality Act known as the "three men at a party clause". This criminalized any "male person who commits with another male person at a party any act which is calculated to stimulate sexual passion or give sexual gratification", and defined a "party" as "any occasion where more than two persons are present".

Clearly, 250 years of criminalization and repression did nothing to eradicate male same sex behavior, but there was very little research in the biomedical field in this population, until the advent of the first cases of AIDS in South Africa in white gay men in 1983 [5, 6]. Initially seen as a gay disease, HIV in South Africa rapidly developed into a generalized heterosexual epidemic over the next few years. One consequence of this was that government funded awareness and prevention campaigns became increasingly heterosexually focused and silent on MSM issues, and very little specific information or MSM targeted services were available, other than through a few small non-governmental groups.

Following the political change in 1994, came the new 1996 South African constitution, which, uniquely in Africa, bans discrimination based on sexual orientation. In 2006, South Africa became the fifth country in the world to legalize same sex marriage. Public opinion, and the expressed views of some politicians and parliamentarians, while currently more accepting of same sex practices than most other African countries, do not fully support this, and stigma still abounds. 
Progressive legislation does not automatically or immediately change public opinion, or, indeed, ensure adequate services for key populations. A growing body of research in South Africa has demonstrated the stigma and discrimination faced by MSM in their daily lives and in their contact with the health services [7, 8]. A number of other studies have started to provide some understanding of the prevalent behaviors and practices that continue to put MSM at higher risk of HIV infection, even within the rampaging generalized epidemic in the country [9, 10]. Current MSM focused research in South Africa encompasses collaborative work between international researchers and a growing number of local South African researchers, and is an expanding field.

This increasing awareness is starting to impact on policy, with the National Strategic Plan on HIV, STI's and TB 2013-2016 designating MSM as a key population group and recommending enhanced service provision and prevention information [11].

\section{The South African Health4Men Program}

The Anova Health Institute, with support from the US President's Plan for AIDS Relief (PEPFAR) through USAID, started a joint program, Health4Men, with the Western Cape Department of Health to provide clinical and HIV prevention services to MSM in 2009, expanding into Soweto in 2010. The Ivan Toms Centre for Men's Health in Cape Town and the Simon Nkoli Centre for Men's Health in Soweto have become centres of excellence in MSM care. These services are a unique collaboration in southern Africa between a non-governmental organization and the state clinic sector, and have served as training and mentoring sites for further expansion of MSM-competent services, both in South Africa and in several other African countries needle [12]. In developing and implementing these projects, it became clear that there was a paucity of behavioral and social science information on MSM in South Africa and their sexual practices, which was necessary to design appropriate interventions for HIV prevention and care. Collaborative research projects with other South African researchers, and universities in the United States and United Kingdom have started to fill this gap.

The Health4Men program has hosted two conferences focused on local research and issues for MSM: "Top2Btm: Health Care for Men who have sex with men" in May 2011, and “Top2Btm: Changing Manscapes" in August 2012. Reports and presentations from these conferences are available from the Anova Health Institute website www.anovahealth.co.za. The genesis of the collection of papers in this supplement came from these conferences and the desire to encourage publication and highlight local research findings.

\section{Understanding MSM Risks and Needs}

The papers collected in this supplement address key issues for HIV prevention and care for South African MSM. These include investigations of correlates of HIV risk in different settings, including types of sexual partnership, psychosocial and sociocultural factors. Attitudes towards HIV testing, as individuals or couples are explored, in addition to information on a more structural approach to HIV prevention within a Cape Town township community. Two opinion pieces discuss the need for combination HIV prevention approaches for these groups of men and the need to research prevention needs and issues for MSM in rural areas.

A common theme through the papers remains the experience and effects of stigma and discrimination on the way in which South African MSM live their lives and how this affects HIV risk. In this respect, we have not come all that far from the prevailing public attitudes of 250 years ago, despite huge legislative and human rights gains. There remains a need for more in depth information especially in underserved and researched areas of the country. Research that contributes to an understanding of sexual risks, social challenges and ways to reach, support and care for MSM in an African context remains vital to our fight against AIDS.

Acknowledgments The Anova Health Institute is supported by the US President's Emergency Plan for AIDS Relief (PEPFAR) program via the US Agency for International Development (USAID) under Cooperative Agreement Numbers 674-A-00-08-00009-00, 674-A1200015 and 674-A12-00028. Publication of this supplement was made possible through these grants. The views expressed in this supplement do not necessarily reflect those of PEPFAR or USAID. Our thanks to Geoff Jobson at the Anova Health Institute for his assistance in compiling the supplement, and to Glenn de Swardt, Kevin Rebe and the staff of Anova's Health4Men program for their support. We would like to thank Dr. Seth Kalichman and the staff of AIDS and Behavior for their guidance, assistance and patience in the preparation of this supplement.

\section{References}

1. Oosterhoff J. Sodomy at sea and at the Cape of Good Hope during the eighteenth century. J Homosex. 1988;16(1-2):229-35.

2. Scully WC. The ridge of the white waters ("witwatersrand") or impressions of a visit to Johannesburg with some notes of Durban, Delagoa Bay, and the low country. London: Stanley Paul \& Co; 1912.

3. Forman RG. Randy on the rand: Portuguese African labor and the discourse on "unnatural vice" in the Transvaal in the early twentieth century. J Hist Sex. 2002;11(4):570-609.

4. Reid GD. T. Understanding systemic violence: homophobic attacks in Johannesburg and its surrounds. Urban Forum. 2002; 13(3):99-126.

5. Sher R. AIDS in Johannesburg. S Afr Med J. 1985;68(3):137-8.

6. Sher R. HIV infection in South Africa, 1982-1988-a review. S Afr Med J. 1989;76(7):314-8. 
7. Lane T, Mogale T, Struthers H, McIntyre J, Kegeles SM. "They see you as a different thing": the experiences of men who have sex with men with healthcare workers in South African township communities. Sex Transm Infect. 2008;84(6):430-3.

8. Rispel LC, Metcalf CA, Cloete A, Moorman J, Reddy V. You become afraid to tell them that you are gay: health service utilization by men who have sex with men in South African cities. J Public Health Policy. 2011;32(Suppl 1):S137-51.

9. Rispel LC, Metcalf CA, Cloete A, Reddy V, Lombard C. HIV prevalence and risk practices among men who have sex with men in two South African cities. J Acquir Immune Defic Syndr. 2011; 57(1):69-76.
10. Wagenaar BH, Sullivan PS, Stephenson R. HIV knowledge and associated factors among internet-using men who have sex with men (MSM) in South Africa and the United States. PloS one. 2012;7(3):e32915.

11. South African National AIDS Council. National strategic plan on HIV, STI's and TB 2013-2016. South African National Aids Council: Pretoria; 2012.

12. Needle R, Fu J, Beyrer C, Loo V, Abdul-Quader AS, McIntyre JA, et al. PEPFAR's evolving HIV prevention approaches for key populations-people who inject drugs, men who have sex with men, and sex workers: progress, challenges, and opportunities. J Acquir Immune Defic Syndr. 2012;60(Suppl 3):S145-51. 